\title{
Contribution of Tea Root Reinforcement to Soil Shear Strength on Slope Stability
}

\author{
Mukhsin \\ Department of Civil Engineering, Faculty of Engineering, Universitas Syiah Kuala, Banda Aceh, INDONESIA \\ mukhsin.abubakar@unsyiah.ac.id
}

\begin{abstract}
Roots played important role in the process of stabilizing the soil mass. The geo-mechanical and soil-hydrological aspects on slope are determined by, one of it, the root reinforcement. Contribution of root branching series with diameter differentiation is greatly determining its tensile stress. The tensile stress from the interaction between the root and the soil, could it contribute to increasing the shear strength of the slope stability. The purpose of this research was to identify the tensile stress on root branching series that interacted with the soil and created additional cohesion as a shear strength contribution to the slope stability. Testing on the root pulling force was conducted on slope prototype with angle 30o to 40o and has been planted with tea vegetation. A tripod that was completed with strain gauge as the recording instrument was used. Testing was conducted on two and three root branching, also on each unit by observing the diameter. This testing method was done in saturated soil condition. The tensile stress result showed that increasing diameter of the tea root, an increase was noticed, and also result in the equation of $\mathrm{TFr}=0.089 \mathrm{e} 0.516 \mathrm{~d}$. Root diameter increase on two and three root branching to one unit of tea vegetation showed that the stress increase was significant. When observed, in the root diameter differentiation of $4 \mathrm{~mm}$ to $6 \mathrm{~mm}$, the stress on two and three root branching and one unit of tea vegetation were respectively 5.94\%, $12.30 \%$, and $35.42 \%$. The contribution of additional cohesion caused by root-soil interaction to soil shear strength apparently could increase slope stability.
\end{abstract}

Keywords: tea, root, slope prototype, shear strength, stability.

\section{INTRODUCTION}

The failure of the slope with big trees and the occurrence of landslide was caused by long heavy rain that was affected by the wind loads (Essays, 2013). Locations that generally has rock layer at shallow depth are very risky to the stability of the slope. If the slope has big trees, this could lead to progressive failure. While on the other hand, rainwater infiltration on location with rock layer at shallow depth could cause an increase in soil volume and also soil mass motion. Therefore, appropriate vegetation selection is needed for the slope stability analysis. Slope failure could be related to several factors, such as climate condition, geology, topography, vegetation, or combinations of these factors. Positive effects of vegetation on slope stability are (i) soil-hydrological aspect, which is root ability to absorb water in soil, and (ii) geo-mechanical aspect, which is reinforcement by root. Geo-mechanical influence contributed greatly to the shear strength of the soil. Shallow landslide occurs on rainy season alongside the sloping hillside; even though there are already quite a number of vegetation exists. Most of the big trees could not contribute to protecting the soil mass because the weight causes the slope failure. The vegetation chosen for slope stability in this research is tea (acalypha siamensis).

Contribution of tensile strength of tea root was studied, one of which is through its characteristics. Tea has a characteristic in which the root branching is spread inside the soil. Tea root series shows many branching with different diameters. Tea vegetation has a significant influence on slope stability because its' less weight and it is protected from the wind blow for the stem is short with small leaves. The problem is on how the tea root reinforcement with its branching series contribution on the slope could increase the stability of the soil mass. Roots could decrease diffusion pressure of soil from the rainwater and decrease landslide risk from the hydrological aspect. From the mechanical aspect, tea root increases tensile stress and shear stress or soil-root cohesion. Tensile 
stress from interaction between root and soil, could it contribute to increasing the shear strength of the slope stability (Udeni et al., 2014).

The purpose of this research was to identify the tensile stress on root branching series that interact with soil and produce additional cohesion as shear strength contribution to the slope stability. Actual behavior from root-soil in shearing force depends on its process of failure mechanism. The benefits of research on tea root reinforcement are able to answer the shear strength value determination of the soil with three ways: stretching, slipping, and damage. Root reinforcement creates additional cohesion $(\Delta s)$ and increases the slope stability, prevents erosion or shallow landslide. Stress testing of root reinforcement caused by root-soil interaction conducted on the slope prototype location by using simple model that created cohesion value. The cohesion value was expected as root reinforcement for it was assumed that maximum tensile stress was reached inside the soil. However, the reality of mass wasting showed that in this case, the tensile stress of the root was different. In addition, pulling the root out would change its shape and several of it came out together with the soil. The root tends to break or dominantly failed on dry soil or the ones with high shear strength. While damp soil or the ones with lower shear strength would show big roots to be lifted out along with the soils. Tensile stress mobilized each unit of the land area used to calculate the value of additional shear strength and affected the soil stability in the slope. Testing for the root tensile stress conducted in slope prototype that has been planted with tea vegetation, with angle $30^{\circ}$ to $40^{\circ}$. Tea root reinforcement with maximum tensile stress is expected to be able to contribute to the increase of the soil shear strength.

Vegetation has long played role in increasing the slope stability (Normaniza et al., 2008). The aspect of root reinforcement in vegetation would increase the slope stability (Chirico et al., 2013). Previous research stated that tensile force of bamboo root could significantly increase the number and diameter. On the other hand, the root tensile strength per soil area would significantly decrease because it is occupied with more roots. This shows that the bamboo branching that interacts with soil could add cohesion value (Mukhsin et al., 2016). On the other hand, previous research stated that tensile force of ratio length/height of agave leaves could significantly increase root number. While the tensile strength of each soil area would decrease because it is being occupied with more roots. Tensile strength per soil area was taken from root-soil interaction, which contributed to the shear strength and created equation of $\Delta \mathrm{s}=1.012 \mathrm{t}$. Additional cohesion contribution to the soil shear strength could increase the slope stability (Mukhsin, 2016).

\section{LITERATURE REVIEW}

Soil shear strength is the soil ability to resist the shear stress that occurred at time it is loaded. If the soil is loaded, the load then would retain due to the effect of soil shear strength, in which the deep shear (Ø) between the soil grains is directly proportional to the vertical stress (effective stress) that works on shear plane and soil cohesion, depends on the soil type and soil density, but not depend from the vertical stress that works on the shear plane.

Vegetation root is the most important part in preventing the landslide, through two mechanisms, which are gripping the soil and supporting the stem as an anchor. According to Abe and Ziemer (1991), vegetation root could help to maintain the slope stability through the increase of soil shear strength. Vegetation on the slope has an important role in hydrology, thus affecting the erosion activity and landslide. Vegetation itself also creates an environment, in which the water is trapped or stored in the soil, particularly at time of dry season (Rietkerk et al., 2004). Rain harvesting is a hydrology process that changes the quantity, time, and the water input and output distribution area. Therefore, the infiltrated rainwater into the soil is absorbed by some of the roots, and also plays important role in the slope drying. Vegetation also could contribute to the slope stability and increase the shear strength through its root reinforcement (Gray and Sotir, 1996). Shallow landslide could occur on slope, which caused by the rainwater infiltration on angle that is bigger than the shear angle of effective soil (Chirico et al., 2013)

Mechanical aspect role in the form of gripping the soil contributes to the soil shear strength, yet highly dependent on factors such as the morphology system, reinforcement, root distribution, and interaction 
between root and soil (Reubens et al., 2007). Presence of vegetation root in soil acts as reinforcement through its cohesion effect and also improves the slope stability (Van Beek et al., 2005). Root reinforcement could be stated in cohesion value through the Mohr-Coulomb failure criteria, in which combination of root-soil could calculate shear strength $(\tau)$ as follows,

$$
\tau=c+\sigma \tan \phi+\Delta s
$$

Whereas $\Delta s$ is additional cohesion from root reinforcement, $\mathrm{c}$ is the soil cohesion value, and $\sigma$ is normal stress. Shear force at soil moving could be translated into root tensile strength. Mobilization of root tensile strength could be broken down into tangential and normal components. With the assumption of elastic root and initially perpendicularly oriented to slip surface, and fully mobilized in tension by the root reinforcement (Wu, 2013).
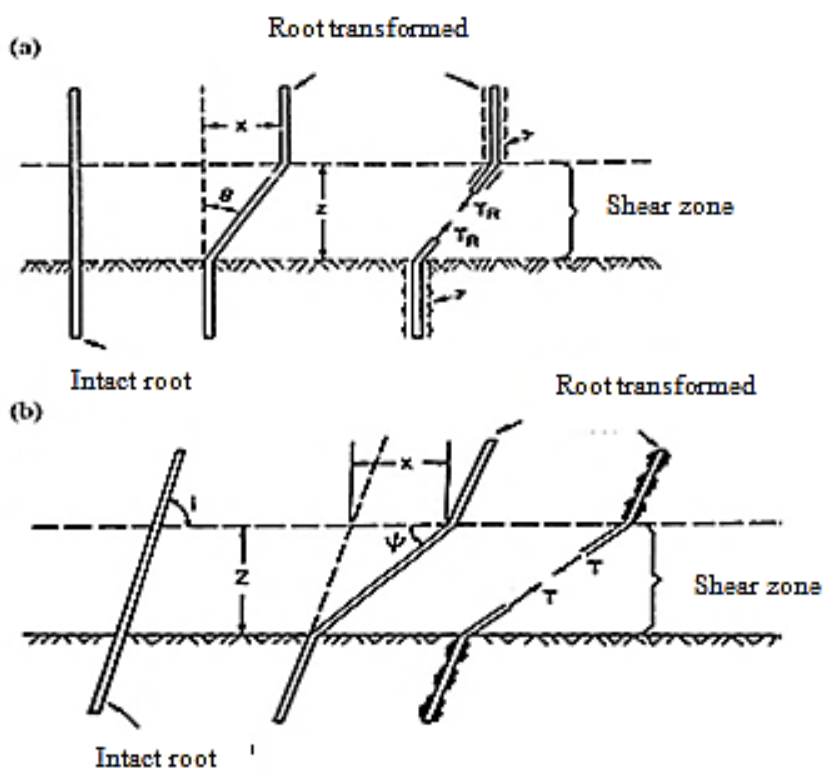

Figure 1. Root reinforcement model; (a) vertical root and (b) slanted root $(\mathrm{Wu}, 2013)$

Value of $\Delta s$ could be defined as follows, as shown in Figure 1a:

$$
\Delta s=t_{r}(\sin \theta+\cos \theta \tan \phi)
$$

In which $t_{r}$ is mean of root tensile strength mobilization per unit soil area, and $\theta=\left(\tan ^{-1} x / z\right)$ is the root angle deflection after a slip, $x$ is the slip movement, and $z$ is the thickness of the slip zone.
On the other side, slanted root as shown in Figure $1 \mathrm{~b}$ with cohesion value addition $(\Delta s)$ from the root reinforcement could be assumed to be following equation (Wu, 2013):

$\Delta s=t_{r}[\sin (90-\psi)+\cos (90-\psi) \tan \phi]$

In which $\psi=\tan ^{-1}\left[1 / m+(\tan i)^{-1}=\right.$ root angle deflection after slip; $i=$ initial slope angle to slip surface; and $m=$ ratio of shear distortion $(m=x / z)$.

\section{RESEARCH METHOD}

Testing on tea root pulling force was conducted on slope prototype with angle ranged from $30^{\circ}$ to $40^{\circ}$. Location of the research was inside Universiti Sains Malaysia (USM) as the slope experiment. A tripod equipped with strain gauge was used as recording instrument. The Handifor 100 strain gauge type (maximum of $100 \mathrm{~N}$ ) was as shown in Figure 2.
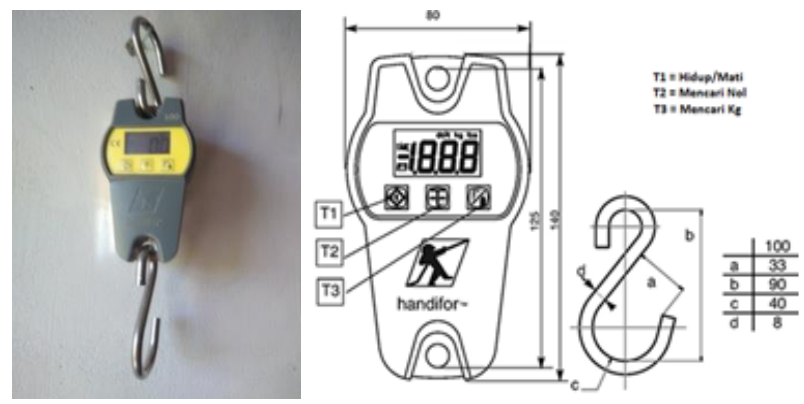

Figure 2. Handifor 100 type equipment and scheme

Before root tensile stress testing was conducted, watering was done in advance around the vegetation in order for the soil became saturated. To ensure that the soil got saturated, moisture measurement was conducted by pressing the soil with Aquater Meter Moisture Probe type T-300 as shown in Figure 3.

The pulling force testing was conducted on per tea vegetation. Testing was also conducted on two and three tea root branching, by cutting the vegetation and digging a bit. The desired root branching was then pulled out with tripod equipped with strain gauge. The tensile stress testing of the tea root was conducted by observing the diameters differences. In this case, the tea root diameter was measured with a caliper tool. 


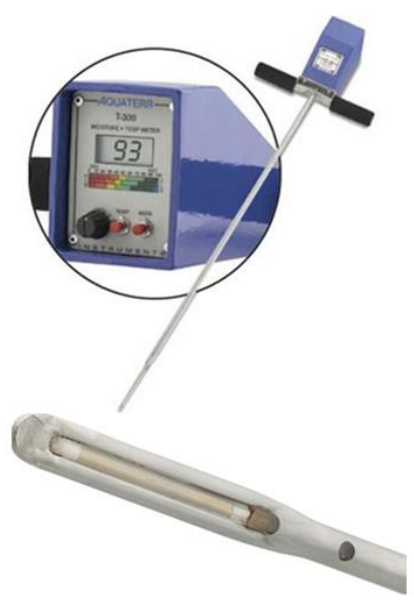

Figure 3. Aquater Meter Moisture Probe type T-300

\section{RESULT AND DISCUSSION}

\subsection{Soil Characteristic}

The research location was on slope prototype with soil characteristic shown in Table 1 , as follows,

Table 1. Soil characteristic

\begin{tabular}{ll}
\hline specific gravity $(\mathrm{SG})$ & 2.661 \\
dry unit weight $\left(\gamma_{\mathrm{dry}}, \mathrm{kN} / \mathrm{m}^{3}\right)$ & 16.292 \\
porosity $(\mathrm{n})$ & 0.303 \\
Plasticity index $(\mathrm{PI}, \%)$ & 31.65 \\
Escaped grain $<0.063 \mathrm{~mm}(\%)$ & 51.68 \\
soil shear angle $(\varnothing)$ & $29^{\circ}$ \\
soil cohesion $(\mathrm{c}, \mathrm{kPa})$ & 20 \\
\hline
\end{tabular}

\subsection{Tensile Stress of Tea Root}

Result of stress per tea vegetation unit by diameter addition showed that it significantly increased, as shown in Figure 4. Graphic on relation between stress and root diameter would generate the following equation,

$$
T F_{r}=0.089 e^{0.51 d}
$$

In which TFr is tensile stress, $\mathrm{d}$ is tea root diameter, and $\mathrm{e}$ is type of exponential regression with $R^{2}=$ 0.884 .

Stress results in two and three root branching showed that it increased along with the adding up of the diameter. When observed, the trend line was a linear regression, which showed that the stress was more significant increase in three branching compared to the two root branching. Tensile stress results in two and three root branching are shown in Figure 5.

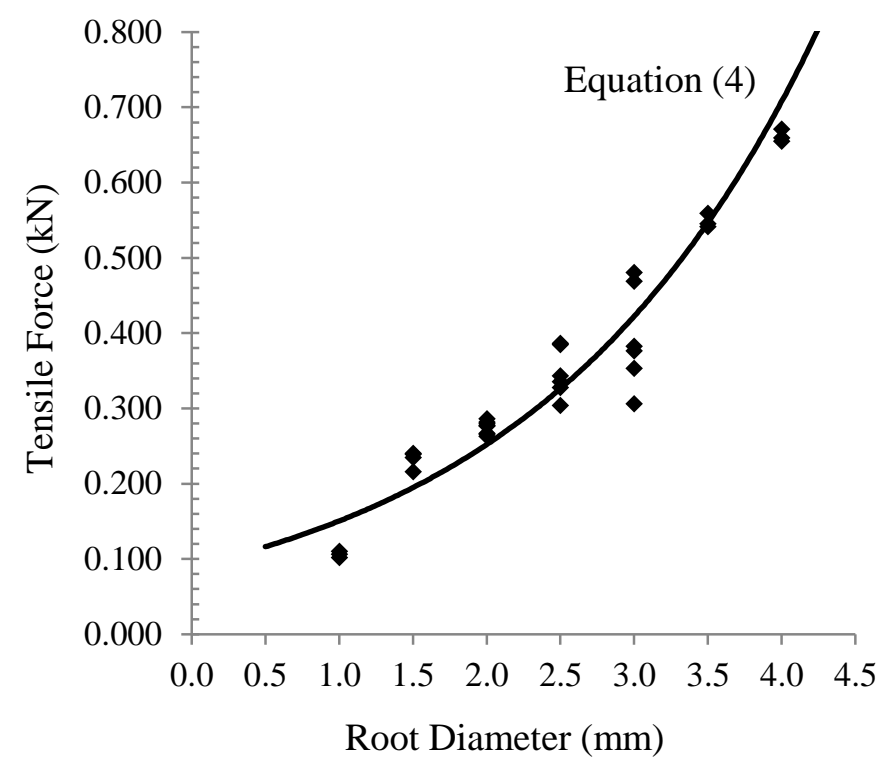

Figure 4. Relation between stress and diameter of tea root

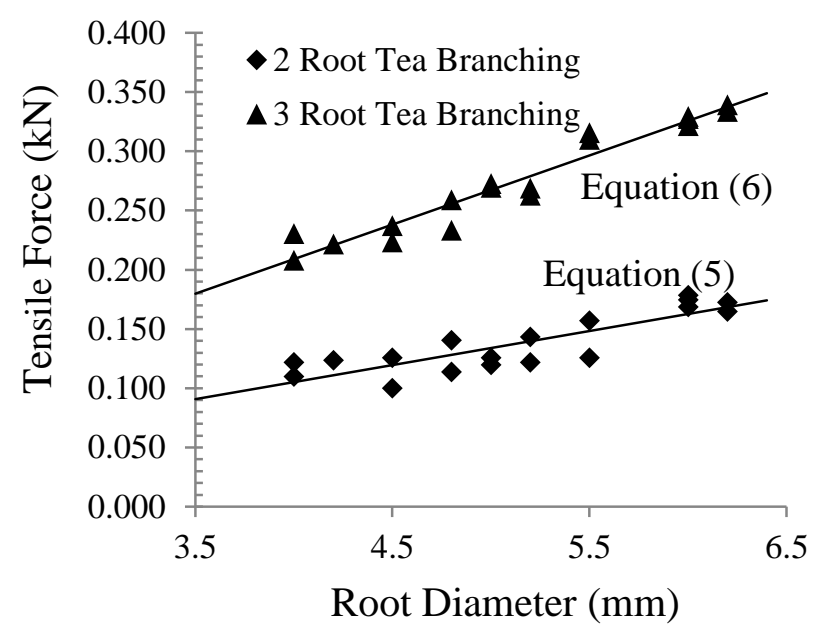

Figure 5. Relation between stress of branching and tea root diameter

Combination between Figure 4 and 5 created graphic as shown in Figure 6. This graphic shows that increase in tensile stress of one unit tea vegetation were very significant, even though the root diameter was smaller. In this case, stress increase caused in one unit vegetation was more than the root branching group amount. The root branching group amount on tea vegetation was very determining the soil stability on slope. 


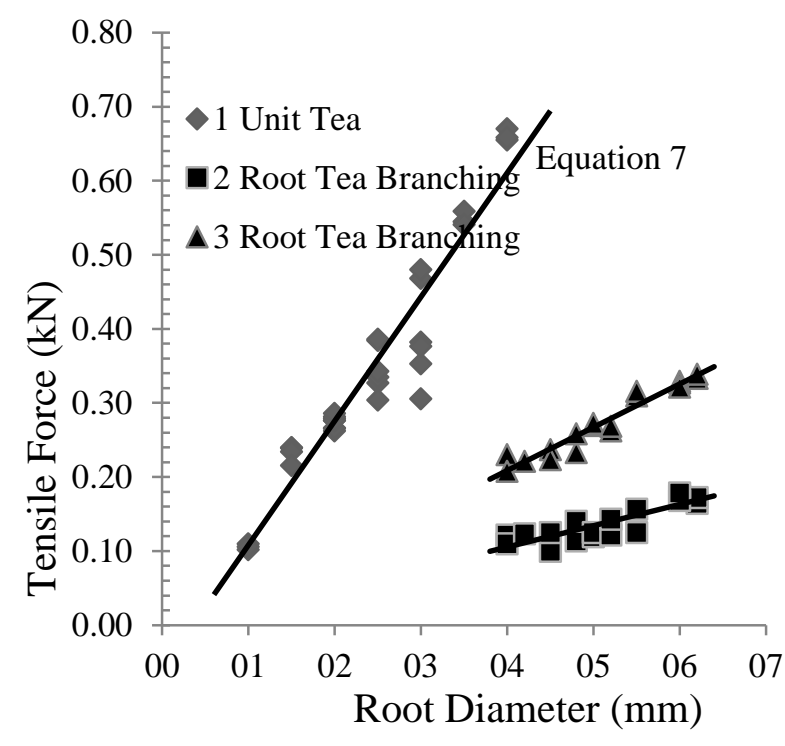

Figure 6. Relation between stresses on one unit tea vegetation with root branching group

From the graphic, the stress results obtained from both root groups and one vegetation unit were shown with linear regression, which resulted in this equation.

$T F_{r}=0.028 d-0.009 ; R^{2}=0.727 ; 2$ Branching

$T F r=0.058 d-0.02 ; R^{2}=0.935 ; 3$ Branching

$T F r=0.17 d-0.059 ; R^{2}=0.917 ; 1$ Unit

Based on the calculation of root diameter difference (4 $\mathrm{mm}$ to $6 \mathrm{~mm}$ ) to two and three branching and one vegetation unit, it showed that the percentage of stress were respectively $5.94 \%, 12.30 \%$, and $35.42 \%$, as shown in Table 2. The graphic on relation between stress on branching groups and one unit tea vegetation show significant stress increase, as shown in Figure 7.

Tea root branching series or group with bigger diameter received maximum stress and broke, then gained the biggest strength before touching with the smaller diameter. The tensile stress then added cohesion value, which was the reinforcement contribution to the tea root quantitative. This was very important in analyzing the soil stability in the slope. Meanwhile, in the case of root reinforcement on stable slope, several criteria that were needed to be considered were the amount and diameter. Maximum stress of bigger root diameter and smaller diameter gave interaction between root and soil and were better to resist the shear. To avoid slipping on slope failure, the root that laterally grows with horizontal direction, with vertical and parallel spreading, could penetrate the dense layer in the slipping zone. This situation assumed that the root that was embedded in the soil with stress was fully mobilized. Therefore, interaction of root and soil generated additional cohesion value as a root reinforcement, in which it contributed to the soil shear strength and could increase the slope stability.

Table 2. Increase percentage of diameter from $4 \mathrm{~mm}$ to $\mathrm{mm}$ on two and three root branching, and one tea vegetation unit

\begin{tabular}{|c|c|c|c|}
\hline \multirow[b]{2}{*}{$\begin{array}{l}\text { Root } \\
\text { diameter }\end{array}$} & \multicolumn{3}{|c|}{ Stress $(\mathrm{kN}, \mathrm{TFr})$} \\
\hline & $\begin{array}{l}2 \text { Root } \\
\text { branching }\end{array}$ & $\begin{array}{l}2 \text { Root } \\
\text { branching }\end{array}$ & $\begin{array}{l}1 \\
\text { vegetation } \\
\text { unit }\end{array}$ \\
\hline $\mathrm{d}=4$ & Equation (5) & Equation (6) & Equation \\
\hline $\mathrm{mm}(\mathrm{a})$ & 0.103 & 0.208 & (7) 0.609 \\
\hline$d=6$ & Equation (5) & Equation (6) & Equation \\
\hline $\mathrm{mm}(\mathrm{b})$ & 0.159 & 0.324 & (7) 0.943 \\
\hline$(b-a)$ & 0.056 & 0.116 & 0.334 \\
\hline$((b-$ & \multicolumn{3}{|l|}{ Increase $(\%)$} \\
\hline a)/(b))*100 & 5.95 & 12.30 & 35.42 \\
\hline
\end{tabular}

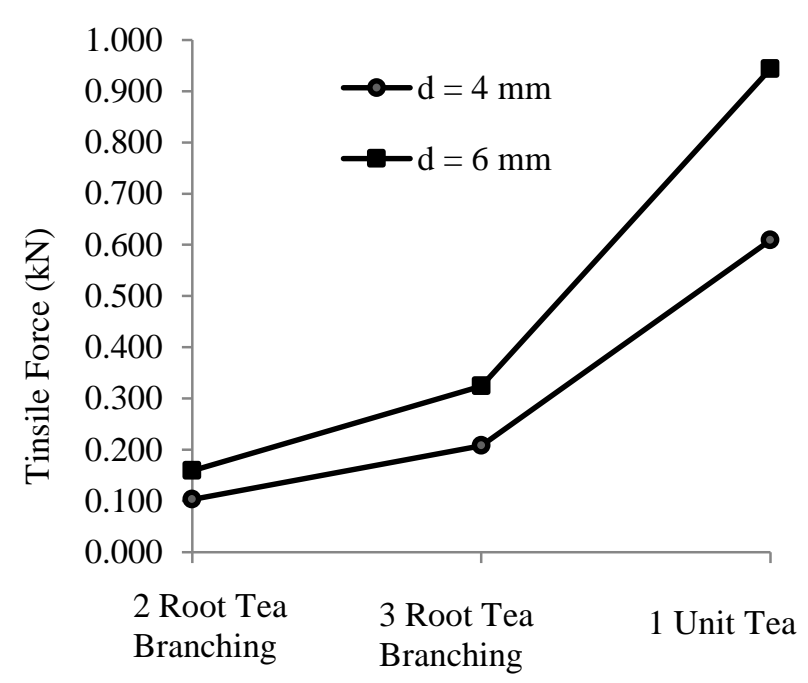

Figure 7. Stress relation of amount of root branching and one tea vegetation unit

\section{CONCLUSION}

Based on the research result of tea root tensile stress contribution to soil shear strength, several conclusion could be made, which are: 
a) Tea root tensile stress increased with the tea root diameter and generated equation of

$$
T F_{r}=0.089 e^{0.51 d}
$$

b) At diameter increase of the root of two and three branching up to one unit tea vegetation, significant stress increase was noted.

c) When observed, in the root diameter differentiation of $4 \mathrm{~mm}$ to $6 \mathrm{~mm}$, the stress on two and three root branching and one unit of tea vegetation were respectively $5.94 \%, 12.30 \%$, and $35.42 \%$.

d) Maximum stress of bigger root diameter and smaller diameter gave interaction between root and soil and were better to resist the shear.

e) Additional cohesion value resulted from root-soil interaction to the soil shear strength could increase the slope stability.

\section{REFERENCES}

Abe, K. \& Ziemer, R. R., 1991. Effect of Tree Roots on a Shear Zone: Modelling Reinforced Shear Strength. Can J Forest, pp. 1012-1019.

Chirico, G. B. et al., 2013. Role of Vegetation on Slope Stability Under Transient Unsaturated Conditions. Procedia Environmental Sciences, pp. 932-941.

Essays, UK, 2013. Effect of Vegetation on Slope Stability Engineering Essay. [Online] Available at: https://www.ukessays.com/essays/engineering/effectof-vegetation-on-slope-stability-engineeringessay.php?cref $=1$

Gray, D. H. \& Sotir, R. B., 1996. Biotechnical and Soil Bioengineering Slope Stabilisation. In: A Practical Guide for Erosion Control. NewYork: Wiley.
Mukhsin, A., 2016. Kekuatan Tarik Akar Vegetasi Agave terhadap Stabilitas Lereng. Bandung, Konferensi Nasional Pascasarjana Teknik Sipil, pp. V1-V9.

Mukhsin, A., Rizalihadi, M. \& Ramadhan, R., 2016. Studi Kekuatan Tarik Akar Bambu terhadap Stabilitas Tanah di Bawah Lereng. Padang, Andalas Civil Engineering National Conference, pp. 377-385.

Nawagamuwa, U. P., Sarangan, S., Janagan, B. \& Neerajapriya, S., 2014. Study on The Effect of Plant Roots for Stability of Slopes. Beijing, World Landslide Forum.

Reubens, B., Poesen, J. \& Danjon, F., 2007. The Role of Fine and Coarse Roots in Shallow Slope Stability and Soil Erosion Control with a Focus on Foot System Architecture.

Rietkerk, M., Dekker, S. C., De Ruiter, P. C. \& Van de Koppel, J., 2004. Self-Organized Patchiness and Catastrophic Shifts in Ecosystems. Science, pp. 19261929.

Van Beek, L. P. et al., 2005. Observation and Simulation of Root Reinforcement on Abandoned Mediterranean Slopes. Plant Soil, pp. 55-74.

Wu, T. H., 2013. Root Reinforcement of Soil: Review of Analytical Models, Test Results and Applications to Design. Canadian Geotechnical Journal, pp. 259274. 